\title{
サンフランシスコにおける道路の広場化デザインに関する考察 \\ ーパークレットとプラザによる人間中心の道路空間の創出 - \\ A STUDY ON THE PARKS DESIGN OF STREETS IN SAN FRANCISCO
}

- Making a human centered street by the Parklet and Plaza -

遠藤 新*

Arata ENDO

\begin{abstract}
This research aims to analyze the "parklet" and "plaza" generated by the Pavement to Parks Program in U.S. San Francisco and to consider the main point in the case of planning, designing and using a street as a place for people's exchange and stationary. The main findings are as follows: It is considered that the pavement to parks program create a human-centered place on the road. The improvement process of plaza and the design of parkelt offer the public-ness in a user viewpoint and the people's comfortableness.
\end{abstract}

Keywords : Parklet, Plaza, Public Space, Street Design, Temporary Improvement, Maintenance and Management パークレット, プラザ, 公共空間, 道路デザイン, 暫定整備, 維持管理

\section{1. はじめに}

\section{1 背景 $\cdot$ 目的}

モータリゼーションの時代に人を脇においやってきた日本の「み ちづくり」は今ようやく転換期を迎えた。2011年 10 月の都市再生 特別措置法改正で認められた「にぎわい・交流の創出のための道路 占用許可の特例」は、道路上にオープンカフェを常設することを可 能にした。これにより、7 年間の社会実験期間を経て特例道路占用 区域を活用するに至った新宿モア 4 番街の道路上オープンカフェや 広告板、都市再生整備推進法人（現・都市再生推進法人）の指定を 受けたエリアマネジメント組織が運営する札幌の大通すわろうテラ ス (食事・購買施設)、グランフロント大阪のオープンカフェと広告 板の設置等といった適用事例が登場することとなった。2014 年 6 月には同じく都市再生特別措置法の特例道路占用区域を活用する

「東京シャンゼリゼプロジェクト」により、東京の新橋・虎ノ門を 結ぶ新虎通りの歩道空間上にオープンカフェが出現した。

これらの適用事例は、1999 年の国土交通省道路局による公募型社 会実験の導入と 2005 年の道路占用許可に関する弾力的な運用基準 「地域の活性化等に資する路上イベントに伴う道路占用の取扱いに ついて」の通知以来、各地で取り組まれてきた社会実験による道路 空間のオープンカフェ等試行ではなく、道路法第 33 条第 1 項にあ る「無余地性の基準」の適用除外と地元エリアマネジメント組織に よる道路空間の占用によるものである。道路空間の賑わい・交流の 創出のための規制緩和は段階的であるが着実に進んできたのである。

これらの適用事例を通じて今あらためて問われるのは、人間中心 の道路空間の作り方・使い方である注 ${ }^{1}$ 。日本よりも早くモータリゼ ーションの影響を受けたアメリカの都市の場合、1990 年代頃から中
心市街地等の再生の切り札として各地に広まった Business Improvement District（BID）制度を通じて、荒廃した屋外公共空間だっ た道路の防犯や美化向上のために、積極的なカフェやイベント利用、 パトロールや清掃等を公民連携で推進してきた。近年は自動車だけ でなく、自転車、車い寸、歩行者など全てのユーザーにとって使い やすい空間へと道路を転じるために、従来の自動車交通の機能性を 重視した工学的な設計標準からの脱却を目指寸計画・デザインや実 践が「コンプリート・ストリート (complete street) 政策」として 多くの自治体に広まった。その一つの潮流に、人間的な感覚と尺度 をもとに、人が交流・滞留するための場所として道路を計画・デザ イン・活用する実践がある。その中でニューヨーク市のプラザプロ グラム、サンフランシスコ市のパークレットは、社会実験から始ま って自治体の制度へと発展し、現在は他の自治体が追随寸る潮流を 産み、アメリカ都市に大きな影響を与えている。パークレットはプ ラザプログラムにヒントを得て、サンフランシスコ市が独自開発し たプログラムである。 2015 年 8 月時点で、北米だけで 46 都市にパ ークレットが設置されている注2)。シアトル、ボストン、フィラデル フィア、シカゴ、ニューヨークなど 13 市においては自治体のプロ グラムとして展開して多数のパークレットが設置されている。

以上を踏まえて本研究では、米国サンフランシスコ市の Pavement to Parks Program（以下 P2P プログラム）によるパークレッ トとプラザを題材に、人間の交流・滞留の場所として道路の一部を 計画・デザイン・利用する場合の課題と要点を分析考察し、その知 見から日本の道路の広場化を進める際の課題を考察する。

\section{2 既往研究}

Gary Benjamin (2013)は、サンフランシスコとニューヨークの

* 工学院大学建築学部まちづくり学科 准教授・博士 (工学) Assoc. Prof., Dept. of Urban Design and Planning, School of Architecture, Kogakuin University, Dr.Eng. 
BID によるプラザプログラムを比較分析し、成功のためには、行政 や BID と地元との協力関係と責任明確化、収益イベントやスポンサ 一確保、場所選定とデザインが成功のためには重要であると指摘し た。Larson, C., Guenther, J. (2012)は、行政プランナーの視点から、 公民連携体制の構築を通じたコミュニティによる地域貢献の機会と してパークレット事業を評価した。Evan F. Peterson (2012)は、モ デル事業時のプラザとパークレットの分析から、協働体制、手続き 簡素化、斬新なプロセスがプログラム導入において重要だと指摘し た。パークレットとプラザの導入効果については San Francisco Planning Department (2014)、San Francisco Great Streets Project $(2009,2010,2011)$ 等が利用等動向を詳細に分析している。 日本語の研究成果としては、渡邊・村山・清水 (2014) が、マニ ユアルの分析から手続き、費用、技術基準を明らかにし、写真分析 からパークレットの構成要素に着目した形態分類を行った。ニュー ヨークのプラザプログラムに関しては、中島（2014）がプログラム 設立経緯を取り上げた。三浦・出口（2014）はプログラムを運用す る主体間の協㗢体制、財源確保手法、満たすべきデザイン条件の 3 項目を分析し、運営組織に対する資金的支援を課題として指摘した。

プラザとパークレットに関連の深い研究として、我が国の道路空 間の占用による人間中心の道路空間の作り方・使い方を分析考察し たものがある。泉山・小林（2013） は都市再生整備推進法人制度を 用いた道路占用の事例（札幌、新宿、大阪）を分析し、収益事業の 確保策としての同制度の活用の可能性を指摘した。三浦・出口

（2015）は、旭川市平和通買物公園を題材として、歩行者専用道路 化したメインストリートの空間利活用とマネジメントにおける留意 点を考察した。その中で、官民の役割分担や民間組織間の協力関係 の構築に加え、活用の幅を規定する「公共性」の概念は「賑わい創 出」及び「市行政との連携」に重点があることを指摘した。

一方、人間中心の道路空間のあり方を問う視点からプラザとパー クレットがつくる道路空間の整備やデザインのあり方を分析した研 究は見られないため、本研究ではこの点を掘り下げて分析考察する。

\section{3 研究方法}

サンフランシスコ市の P2P プログラムを用いて全市的広がりで成 果を上げているプラザとパークレットを本研究では調查対象とした 注3)。プラザは道路の一部を人が滞留できるよう広場化するもの、 パークレットは道路の路駐区画に人が滞留できるような設えやファ ニチャを仮設して駐車帯の広場化を行うものである。市のウェブサ イト情報を用いてパークレットとプラザの位置を特定し、2013 年か ら 2015 年にかけて 3 回の現地調查を実施した (2013 年 3 月 4 日〜9 日，同年 11 月 18 日～ 23 日， 2015 年 3 月 9 日〜 14 日）。 2013 年調 查時には現地確認できたが 2015 年 3 月調查時までに撤去が確認され たパークレット 5 件とプラザ 1 件は分析対象から除外した。

研究は、まず文献調查によって P P P゚ログラムの創設経緯と制度 概要を明らかにする（第 2 章）。次に、全てのパークレットとプラ ザを対象にデザインの前提条件となる立地動向を分析する。さらに パークレットとプラザのデザイン特性および維持管理状態の実態を 分析し、人にとってのどのような場所を生み出しているのかを明ら かにする（第 3 章）。次に、ケーススタディとして近隣団体が手が けたパークレットとプラザを抽出してヒアリング調査を行い、整備 の背景と目的、デザインと整備プロセス、維持管理の方法と課題を
分析し、その要点を明らかにする（第 4 章）。日本の道路占用によ る常設オープンカフェや休㮩空間の大半が地元の商店会やエリアマ ネジメント組織等が運営の中心的役割を担っていることから、こう した組織にとって有用な知見を得るためにケースススタディは近隣 団体（BID 法人、CBD 法人、NPO 法人、商店街組織、任意団体）が手 がけたものを対象とした。全パークレットとプラザの整備主体を調 べ、調查候補として選出した 8 団体にヒアリング調查を申し込み、 承諾された 5 団体（パークレットのみ整備主体 2 団体、プラザのみ 整備主体 2 団体、パークレット及びプラザ整備主体 1 団体）から得 られた情報を分析した（表 1 ）。最後に以上の分析から得られた知 見を整理して、人間の交流・滞留のための場所として道路を計画・ デザイン・利活用する場合の課題や留意点、それらの知見から日本 の道路の広場化を進める際の課題を考察した。

表 1 ヒアリング調査実施団体一覧

\begin{tabular}{|l|l|}
\hline 組織名（訪問日時・訪問相手） & 調査対象パークレット,プラザ \\
\hline $\begin{array}{l}\text { Union Square BID (2015/3/10, 11:30-12:15, Claud Imbault, } \\
\text { Director of Strategic Initiatives) }\end{array}$ & Powell Street Parklet \\
\hline $\begin{array}{l}\text { Castro/Upper Market CBD (2015/3/10. 10:00-10:45. } \\
\text { Andrea Aiello, Executive Director) }\end{array}$ & Jane Warner Plaza \\
\hline $\begin{array}{l}\text { Excelsior Action Group (2015/3/11. 14:00pm-15:30. } \\
\text { Stephanie Cajina, Executive Director) }\end{array}$ & $\begin{array}{l}\text { Persia Triangle Plaza, } 4754 \\
\text { Mission St. Parklet }\end{array}$ \\
\hline $\begin{array}{l}\text { Ocean Avenue Association (2015/3/11. 10:00-11:30. Daniel } \\
\text { Weaver, Executive Director) }\end{array}$ & 1901 Ocean Ave Parklet \\
\hline $\begin{array}{l}\text { Yerba Buena CBD (2015/3/13. 9:00-10:00. Andrew } \\
\text { Robinson, Director of Neighborhood Partnerships) }\end{array}$ & Annie Street Plaza \\
\hline
\end{tabular}

2. ペイブメント・トゥ・パークス・プログラム (P2P プログラム)

\section{1. プログラム創設の経緯}

始まりは 2005 年に SOMA（South of Market）地区の路上で地元の 設計事務所 ReBar が企画実施した 1 日イベントParking Day である とされる注 4)。イベントでは路上駐車スペースを借りて植栽やベン チ等が置かれ、人が活用して賑わいを見せた。その後、2006 年 2 月 にサンフランシスコ市議会は、道路の性能を自動車交通機能に特化 させすぎず、歩行者志向の道路空間づくりを方向づけるべく、Better Streets Policy (San Francisco Administrative Code, Sec. 98.1. BETTER STREETS POLICY）を採択した。同年秋には、方針を具体化す るため、街路に対する歩行者空間および街路景観としての特徴を定 めたデザインガイドラインづくりを市計画局が着手した。市民との 協議を経て 2010 年には Better Streets Plan が策定された。計画は サンフランシスコ市・郡における街路空間の指針であり、パブリッ クライフのための空間、駐車帯の創造的活用といった歩行者志向の 道路空間づくりのための 10 の主要なテーマが位置付けられた。

この計画の過程で P $2 P$ プログラムは創設された。2008 年半ば、計 画局が道路空間の暫定利用と道路駐車帯の創造的な活用について議 論する中、当時ニューヨーク市交通局理事カーン氏を招聘し、市の 公共事業局長（Ed Reiskin 氏）、計画局長（John Rahim氏）、交 通局主任（Nat Ford 氏）、市長室スタッフがニューヨークでの道路 空間の広場化の取り組みについて聞くこととなる。これを受けて市 内での同様のプロジェクト展開の可能性の検討が始まり、庁内で進 行中の取り組みやコミュニティ計画の内容を吟味した結果、当時計 画中だったUpper Market Streetscape Plan に位置付けられていた カストロ地区 17th Street Plaza（現 Jane Warner Plaza）整備が最 初のパイロット事業に指定された。2009 年には道路の一部が実験的 に暫定広場化された。同広場は 2010 年に本格的整備が行われた。さ 
らに道路の 1 列を暫定かつ安価に広場化することを目標として、パ ークレットと称する新しい道路上仮設広場の設置プログラムを市は 開始した。2010 年に市内 3 路線・5 箇所においてパイロット事業 (実 証実験＆調查）を実施し、その成果を踏まえて 2011 年以降の本格実 施となった注 5)

\section{2. パークレット設置とプラザ整備の仕組み}

道路および公共通行権（public rights-of-way）の設定領域は市内 の土地の 25\%（=公園面積の総和より大）を占めるとされるが、実

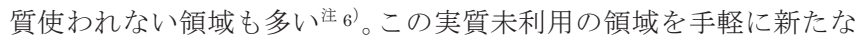
歩行者空間へと転換する試みが $\mathrm{P} 2 \mathrm{P}$ プログラムである。プログラム の目標には表 2 に示寸 5 つが掲げられている。

パークレットに関しては完成までの流れとガイドラインが 1 冊の マニュアルに整理され、公表されている。完成までには設置者のほ かサンフランシスコ市の計画局、交通局、公共事業局が図 1 の流れ で関わることになる。毎年設置プロポーザルの受付があり、パーク レットの設置希望者が応募すれば、市の関係機関が審查・採択する。 設置者には敷地周辺への告知、資金負担（手続き、制作設置に関す る一式)、パークレットのデザイン・制作・設置、設置後の様々な責 務（維持管理等）といった役割が求められる。市側は計画局が申請 受付事務とデザイン協議および審查、交通局が交通関連の審查、公 共事業局が法令及び性能審査（Public Works Code, Public Works Standards）と工事中および竣工後の検查、維持管理・修繥・使用に 関する協定の締結といった役割を担う。

\section{表 2 P2P プログラムの目標(出典 : 参考文献 15)}

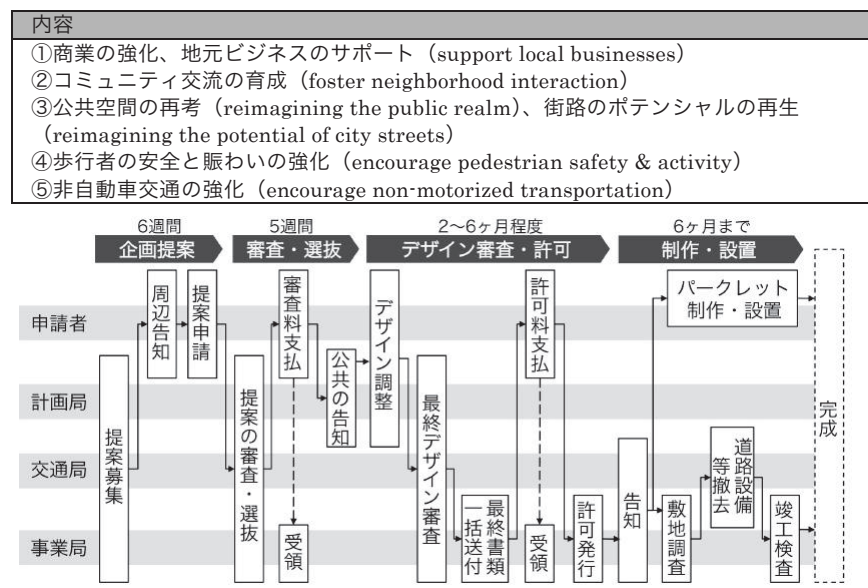

図 1 パークレット提案から設置までの手続きの流れ（筆者作成）

マニュアルでは企画提案、デザイン、制作と設置、設置後までの 流れを 4 つに区分して重要事項を定めている（表 3 )。マニュアルが 示す性能要件とガイドラインを満たす範囲において、創造的なデザ インが推奨されている。基礎工事は禁止で、撤去可能な仕様が求め られる。パークレットの設置場所には基準が定められ（表 4 ）、審査 の際に参照される。P2P プログラムにおいて、パークレットの設置 者は「提供者（host）」と称される。つまり、所有者や管理者ではな く「公共に対して場を提供する人」という捉え方である。そのこと は、マニュアルの各所に「パークレットは公共に開かれている

(parklets are public)」と記載されていることからもわかる。設 置後は市の公共事業局と設置者の間で「公共への開放（pub1ic access requirements)」および「適切な維持管理（maintenance agreement)」について協定を締結する。

プラザは市と地元組織による協働事業である。整備までの段取り は明示されていないが、地元から市に対して整備を要望するための 必要図書と書式は公表されている注7)。要望時の必要図書には、周辺 を含む広場構想 (context plan)、敷地計画、現況写真、コンセプト 説明、広場のイベント・活用計画（日程表）、維持修繥計画、建物所 有者への告知証明、近隣への告知内容等がある。書式には、申請す る組織団体の情報（簡単な財務情報も含む）、広場プロジェクトの資 金計画、活用計画（時間帯、曜日）、維持修繯の収支計画（ゴミ箱の 清掃とゴミ回収、可動設置物の配置・撤去・清掃、路面と側溝の清 掃、植栽の水やり、路面の検査、植栽エリアの検査、植栽の状態の 検查、路面の高圧洗浄、可動設置物の修理・取り替え、落書き削除、 コミュニケーションと地域奉仕）についての記入欄がある。プラザ の推奨立地場所について市はガイドラインを示している（表 5 )。

\begin{tabular}{|c|c|}
\hline & 項目 \\
\hline $\begin{array}{l}\text { 敷地選定 } \\
\text { と周辺告 } \\
\text { 知 }\end{array}$ & $\begin{array}{l}\text { (1)敷地選定基準（制限速度、既存駐車帯、角地・自動車道・その他に面す } \\
\text { る場合、スロープ、駐停車制限路側（color curb）、公共交通路線、道路 } \\
\text { 設備、市の長期計画路線）/(2)敷地計画の作成について、敷地の現況写真、 } \\
\text { 提案の骨子（3)居辺告知について（建物所有者、近隣事業者、地区議員、 } \\
\text { 近隣・商店街組織、近隣住民） }\end{array}$ \\
\hline 審査と選定 & (4)審査 - 許可手数料、公知手段と期間、公共の告知 \\
\hline $\begin{array}{l}\text { デザイン } \\
\text { と許可 }\end{array}$ & 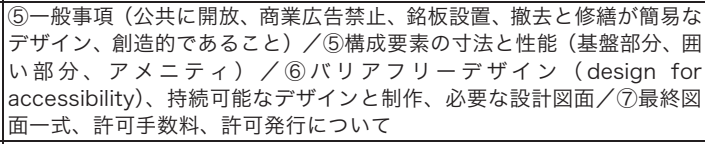 \\
\hline $\begin{array}{l}\text { 素材と設 } \\
\text { 置 }\end{array}$ & $\begin{array}{l}\text { 8)購入必要備品（駐車禁止サイン、ソフト素材の車止め、車輪止め、銘板) } \\
\text { 9検查と設置（既存駐車メーターと自転車ラックの撤去、設置前の敷地調 } \\
\text { 査、設置について、竣工検査） }\end{array}$ \\
\hline 設置後 & $\begin{array}{l}\text { (10)設置者の責務（公共への開放、維持管理、許可の年更新と保険、所有権罯 } \\
\text { の変更時、撤去時（設置者が撤去、道路の原状回復、公共の安)，影食 } \\
\text { 調查、公聴会 }\end{array}$ \\
\hline
\end{tabular}

表 4 パークレットの設置場所基準（出典：参考文献 18）

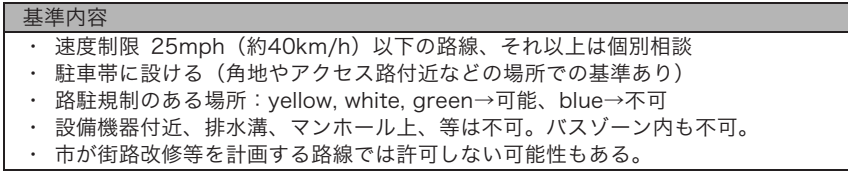

\section{表 5 プラザの立地ガイドライン (出典 : 参考文献 16)}

\section{基準内容}

役に立っていない相当な広さを持った道路空間

近隣に公共空間が不足している

公共空間のコミュニティ支援の既存の体制がある

歩行者および自転車の安全性を改善できる可能性がある

人々を魅了しかつ空間を活性化する用途が周辺に存在する

地元コミュニティや事業の監督者が明確である

\section{3. プラザとパークレットの整備動向}

3. 1. 立地動向

2015 年 3 月までの設置実績はパークレットが 49 箇所、プラザが 5 箇所、合計 54 箇所である（表 6 )。プラザは暫定整備段階のものが 3 箇所、本格的整備が完了したものは 2 箇所（Jane Warner Plaza, Naples Green）であった。パークレットの整備主体の属性は飲食店 舗 40 件、飲食以外の店舗 5 件、個人住宅 1 件、近隣団体 3 件（BID 法人 1 件、 CBD 法人注 ${ }^{8)} 1$ 件、NP0 法人 1 件）であった。飲食店にと っては、店舗前に人が滞留できる場所が設置されると、自店の商品 のテイクアウトの場所として利用できる可能性が広がるため、パー クレットの設置には直接的なメリットがあると考えられる。プラザ の整備主体は全て近隣団体で、その属性は CBD 法人 2 件、商店街組 
織 1 件、NP0 1 件、任意団体 1 件であった。

次にプラザとパークレットの場所特性を分析する。前面の宅地の 用途地域規制に着目すると、54箇所のうち 43 箇所は路面店が通り 沿いに並ぶ近隣商業系の用途地域指定（NCD, NCTD）注9) である（表 7 )。近隣商業系の用途は 8 つ区分され、そのうち 2 区分は商店街 等のように近隣店舗の集積が通りの個性を形成する地区として地域 特性を踏まえた規制を行う用途地域となっている。この地域特性を 踏まえた近隣商業地域は合計 32 地区が存在するが、その 6 割以上と なる 19 地区にパークレットまたはプラザが整備されている。また、 この 19 地区に NC 地区内のパークレットおよびプラザの合計 8 割に
相当する 34 箇所（全体の 6 割）が集中立地している。このように、 パークレット及びプラザが設置・整備されている道路の半数以上は、 近隣商業型の路面店の集積によって特徴づけられている。

続いて、市内の公共交通路線 (バス、路面電車) とパークレット およびプラザの分布動向の関係を見ると、全 53 箇所のうち 45 箇所 が公共交通路線に面している（図 2 ） 注 10)。総じてサンフランシス コ市内のバスの乗降場所はバス路線に沿って数街区に一箇所ほどの 短い間隔で設置されていることから注 11)、これらのパークレットお よびプラザは公共的なアクセスが得られやすい（不特定多数が利用 しやすい）立地にあることがわかる。

表 6 整備済みのパークレット及びプラザー覧（2015 年 3 月時点、筆者作成）

\begin{tabular}{|c|c|c|c|c|c|c|c|c|c|c|c|c|c|c|c|}
\hline 番号 & 場所 & 設置年月 & $\begin{array}{c}\text { ゾーニン } \\
\text { グ }\end{array}$ & 設置・管理者 & 管理者分類 & $\begin{array}{l}\text { テ } \\
\text { ラ } \\
\text { ス } \\
\text { 席 }\end{array}$ & $\begin{array}{l}\text { 公 } \\
\text { 共 } \\
\text { 交 } \\
\text { 通 } \\
\text { 路 } \\
\text { 線 } \\
\end{array}$ & $\begin{array}{c}\text { 清 } \\
\text { 掃 } \\
\text { 維 } \\
\text { 持 }\end{array}$ & $\begin{array}{c}\text { 調査時の利用状況 } \\
\text { (数字は人数、数字の区別は利 } \\
\text { 用者集団の区別を表す) }\end{array}$ & $\begin{array}{l}\text { 基 } \\
\text { 壇 } \\
\cdot \\
\text { 舗 } \\
\text { 装 }\end{array}$ & $\begin{array}{c}\text { A } \\
1\end{array}$ & $\begin{array}{l}\text { A } \\
2\end{array}$ & $\begin{array}{l}\text { A } \\
3\end{array}$ & $\begin{array}{l}\text { A } \\
4\end{array}$ & $\begin{array}{l}\text { A } \\
5\end{array}$ \\
\hline PT01 & 639 Divisadero $\mathrm{St}$ & 2010.03 & NCD & Mojo Bicycle Cafe. & $\mathrm{B}$ & $\circ$ & 0 & $\circ$ & 着座(2)、対話 $(2,2)$ & WD & $\circ$ & $x$ & $\circ$ & $\circ$ & $\circ$ \\
\hline PT02 & 423 Columbus Ave & 2010.10 & NCD & Caffe Greco & $\mathrm{A}$ & $\circ$ & 0 & 0 & 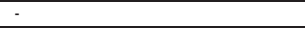 & WD & $\circ$ & $\mathrm{x}$ & 0 & 0 & $x$ \\
\hline PT03 & 3982 24th St & 2010.12 & NCD & Just for Fun + NVMA & $\mathrm{C}$ (雑貨) $+\mathrm{D}$ & - & $\circ$ & 0 & - & $\mathrm{CC}$ & $\circ$ & $x$ & 0 & $\circ$ & $x$ \\
\hline PT04 & 3868 24th St & 2010.12 & NCD & Martha \& Bros Coffee+NVMA & $\mathrm{A}+\mathrm{D}$ & $\circ$ & 0 & $\circ$ & 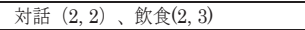 & $\mathrm{CC}$ & $\circ$ & $x$ & 0 & 0 & $x$ \\
\hline PT05 & 360016 th St & 2011.03 & NCT & Squat \& Gobble Café & $\mathrm{A}$ & $\circ$ & - & 0 & 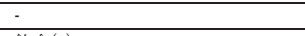 & WD & $\circ$ & $x$ & 0 & $\circ$ & $x$ \\
\hline PT06 & 914 Valencia St & 2011.03 & NCT & Freewheel Bike Shop & B & - & - & $\circ$ & 飲食(1) & $\mathrm{AG}$ & $\circ$ & $\circ$ & $x$ & $\circ \circ$ & o \\
\hline PT07 & 1234 Polk St & 2011.05 & NCD & Quetzal Café & A & $\circ$ & 0 & 0 & & WD & $\#$ & $x$ & $x$ & 0 & 0 \\
\hline PT08 & 1755 Polk St & 2011.05 & NCD & The Crepe House / Bone Flowers & A & $\circ$ & $\circ$ & $\circ$ & 着座(2) & $\mathrm{CC}$ & $x$ & $x$ & 0 & $\circ$ & $\circ$ \\
\hline PT09 & 526 Columbus Ave & 2011.05 & NCD & Caffe Roma & A & $\circ$ & 0 & 0 & - & WD & $\circ$ & $x$ & $\mathrm{x}$ & 0 & $x$ \\
\hline PT10 & 937 Valencia St & 2011.06 & NCT & Amandeep Jawa（住民） & $\mathrm{A}$ & - & - & $\circ$ & - & $\mathrm{CC}$ & $\circ$ & $x$ & $x$ & $\circ$ & $\circ$ \\
\hline PT11 & 375 Valencia St & 2011.06 & NCT & Four Barrel Coffee & $\mathrm{A}$ & - & - & $\circ$ & 飲食+対話 $(2,3)$, 飲食十携帯(1) & $\mathrm{BR}$ & $\times$ & $\circ$ & 0 & $x$ & $\circ$ \\
\hline PT12 & 1132 Valencia $\mathrm{St}$ & 2011.06 & NCT & The Crepe House /Zaytoon Wraps & $\mathrm{A}$ & $\circ$ & - & $\circ$ & 飲食(1) & $\mathrm{CC}$ & $x$ & $x$ & $\circ$ & 0 & $x$ \\
\hline PT13 & 1300 Fulton St & 2011.06 & NCD & Cafe Abir & A & $\circ$ & - & 0 & 飲食(1) & $\mathrm{CC}$ & $\circ$ & 0 & $x$ & 0 & $x$ \\
\hline PT14 & 103-274 Powell St & 2011.07 & $\mathrm{C}-3-\mathrm{R}$ & Union Square BID & $\mathrm{D}$ & - & 0 & $\circ$ & 着座 $(1,1)$, 地図読(1) & ST & $\circ$ & $x$ & $x$ & 0 & $x$ \\
\hline PT15 & 78 29th St & 2011.07 & $\mathrm{NC}-3$ & Cafe Seventy8 & A & - & - & $\circ$ & - & WD & $x$ & $\mathrm{x}$ & 0 & 0 & 0 \\
\hline PT16 & 1570 Stockton $\mathrm{St}$ & 2011.07 & $\mathrm{NCD}$ & Tony's Coal-Fired Pizza / Slice House & $\mathrm{A}$ & $\circ$ & 0 & $\circ$ & 飲食(1) & WD & $\circ$ & $x$ & 0 & $\circ$ & $x$ \\
\hline PT17 & 1315 18th St & 2011.08 & $\mathrm{NC}-2$ & Farley's. & A & 0 & 0 & 0 & 着座(1) & $\mathrm{AG}$ & 0 & 0 & 0 & 0 & 0 \\
\hline PT18 & 384 Hayes $\mathrm{St}$ & 2011.09 & $\mathrm{NCT}$ & Mad Wills Food Co and Arlequin. & A & $\circ$ & $\circ$ & $\circ$ & 携帯 $(1,1)$, , 飲食+携带(1) & $\mathrm{CC}$ & $x$ & $x$ & $\circ$ & $\circ$ & $x$ \\
\hline PT19 & 13319th Ave & 2011.09 & NCD & Arizmendi Bakery & $\mathrm{A}$ & $\circ$ & $\circ$ & $\circ$ & 飲食 $(1,1) 、$ 飲食+遊び $(1)$ & WD & $\circ$ & $\circ$ & $\circ$ & $\circ$ & $\circ$ \\
\hline PT20 & \begin{tabular}{|l|}
$3318-3320$ 22nd St \\
\end{tabular} & 2011.09 & NCT & Fabric 8/Luna Rienne Gallery & C (雑貨) & - & - & $\circ$ & - & WD & $\circ$ & $x$ & $\circ$ & $\circ$ & $\circ$ \\
\hline PT21 & 4033 Judah St & $\begin{array}{l}2011.09+ \\
2013.9\end{array}$ & $\mathrm{NC}-1$ & Trouble Coffee & $\mathrm{A}$ & $\circ$ & $\circ$ & $\circ$ & $\begin{array}{l}\text { 着座(1)、もたれかかり+携帯 (1), } \\
\text { 対話(2) }\end{array}$ & $\mathrm{CC}$ & $\circ$ & $\circ$ & $x$ & $\circ$ & $\circ$ \\
\hline PT22 & 3876 Noriega St & 2011.12 & NC-1 & Devil's Teeth Baking Company & $\mathrm{C}($ パン) & - & $\circ$ & $\circ$ & $\cdot$ & $\mathrm{CC}$ & $\circ$ & $\circ$ & $x$ & $\circ$ & $x$ \\
\hline PT23 & 544 Jones St & 2012.02 & $\mathrm{RC}-4$ & Nile Cafe & $\mathrm{A}$ & - & 0 & $x$ & - & WD & $x$ & $x$ & $x$ & $x$ & $x$ \\
\hline PT24 & 4754 Mission St & 2012.04 & NCD & $\begin{array}{l}\text { Mama Art Cafe and Excelsior } \\
\text { Action Group }\end{array}$ & $\mathrm{A}$ & $\circ$ & $\circ$ & $\circ$ & - & $\mathrm{CC}$ & $\circ$ & $\circ$ & $x$ & $\circ$ & $\circ$ \\
\hline PT25 & 990 Polk St & 2012.06 & $\mathrm{NC}-3$ & JEBENA CAFÉ & A & - & 0 & $\circ$ & - & WD & $x$ & 0 & 0 & 0 & $\circ$ \\
\hline PT26 & 754 Post St & 2012.06 & $\mathrm{RC}-4$ & Farm Table & A & 0 & 0 & $\circ$ & - & WD & 0 & $\circ$ & $x$ & 0 & 0 \\
\hline PT27 & 2410 California St & 2012.06 & NCD & $\begin{array}{l}\text { Siol Design, Zinc Details, and } \\
\text { Pizzeria Delfina. }\end{array}$ & A & $\circ$ & $\circ$ & $\circ$ & 飲食（1） & $\mathrm{CC}$ & $\circ$ & 0 & $\circ$ & $\circ$ & $x$ \\
\hline PT28 & 533 Jones St & 2012.07 & $\mathrm{RC}-4$ & Karachi Classics & A & - & 0 & $x$ & - & WD & $x$ & $x$ & 0 & $x$ & $x$ \\
\hline PT29 & 4001 Judah Street & 2012.07 & $\mathrm{NC}-1$ & Outerlands & A & 0 & - & 0 & - & $\mathrm{CC}$ & 0 & 0 & $\mathrm{x}$ & 0 & 0 \\
\hline PT30 & 212 Ritch St & 2012.7 & SLI & Darwin Café & A & $\circ$ & - & $\circ$ & 飲食+対話 $(2,3)$ & WD & $x$ & $x$ & 0 & $\circ$ & $\circ$ \\
\hline PT31 & 990 Valencia St & 2012.08 & NCT & The Blue Fig & A & $\circ$ & - & 0 & - & $\mathrm{CC}$ & $\circ$ & 0 & 0 & 0 & $x$ \\
\hline PT32 & 1530 Haight $\mathrm{St}$ & 2012.09 & NCD & Haight Street Market & $\mathrm{C}($ スーパー) & - & $\circ$ & $\circ$ & 手芸(1),携带(1), 飲食 $(1,1,1,1)$ & $\mathrm{CC}$ & $\circ$ & $\circ$ & 0 & 0 & $\circ$ \\
\hline PT33 & 236 Townsend & 2012.09 & SLI & D'Urso Italian Delicatessen & $\mathrm{A}$ & $\circ$ & 0 & $\circ$ & & WD & $\circ$ & $\circ$ & $\circ$ & $x$ & $\circ$ \\
\hline РT34 & 2198 Filbert St & 2012.11 & NCD & RAPHA CYCLE CLUB & C (スポーツ) & - & $\cdot$ & $\circ$ & $\begin{array}{l}\mathrm{PC} \text { 作業+飲食 }(1,1) \text { 、読書+飲食 } \\
(1) \text { 、談話+飲食 }(2)\end{array}$ & WD & $\circ$ & $\circ$ & $x$ & $\circ$ & $\circ$ \\
\hline PT35 & \begin{tabular}{|l|}
1122 Folsom St \\
\end{tabular} & 2013.01 & NCT & Brainwash Café & $\mathrm{A}$ & $\circ$ & 0 & $\circ$ & 携带（1），飲食(1), 着座(1) & $\mathrm{CC}$ & $\circ$ & $x$ & 0 & 0 & $x$ \\
\hline PT36 & 354 11th St & 2013.06 & WMUO & BUTTER & $\mathrm{A}$ & - & 0 & $\circ$ & - & $\mathrm{AG}$ & $\circ$ & 0 & 0 & 0 & 0 \\
\hline PT37 & 371 11th St & 2013.06 & WMUO & DNA PIZZA & A & - & $\circ$ & $\circ$ & $\begin{array}{l}\text { 立ち寄り十談話(2)、立ち寄り+携带 } \\
\text { (1),立ち寄り (1) }\end{array}$ & $\mathrm{CC}$ & $\times$ & $x$ & $\circ$ & $x$ & $\circ$ \\
\hline PT38 & 200 Clement St & 2013.08 & NCD & CUMAICA & A & - & - & $x$ & - & WD & 0 & 0 & $x$ & 0 & $x$ \\
\hline PT39 & 732 22nd St & 2013.09 & NCT-2 & JUST FOR YOU CAFÉ & A & - & 0 & $\circ$ & - & WD & $\circ$ & $\mathrm{x}$ & $\mathrm{x}$ & 0 & $x$ \\
\hline PT40 & 1398 Haight St & 2013.10 & NCD & MAGNOLIA & A & $\circ$ & 0 & $\circ$ & 着座(1)、談話(2) & ST & $\circ$ & $\times$ & $x$ & $\circ$ & $\circ$ \\
\hline PT41 & 1730 Yosemite $\mathrm{St}$ & 2013.12 & $\mathrm{M}-1$ & TROUBLE COFFEE CO. & $\mathrm{A}$ & - & - & $\circ$ & & $\mathrm{CC}$ & $\circ$ & 0 & $x$ & 0 & $\circ$ \\
\hline PT42 & 200 Columbus Ave & 2014.04 & NCD & REVEILLE COFFEE CO & A & $\circ$ & 0 & 0 & 飲食(1)、PC (1) 、談話+飲食 (2) & ST & $\circ$ & 0 & 0 & 0 & 0 \\
\hline PT43 & 3434 Balboa St & 2014.04 & $\mathrm{NC}-2$ & SIMPLE PLEASURES CAFÉ & A & $\circ$ & 0 & $\circ$ & 飲食(1) & WD & $\circ$ & $\circ$ & $x$ & $\circ$ & $x$ \\
\hline PT44 & 736 Divisadero $\mathrm{St}$ & 2014.04 & NCD & THE MILL & A & - & 0 & $\circ$ & 飲食(1), 談話（2） & BR & $\circ$ & $\circ$ & $\mathrm{x}$ & $\circ$ & 0 \\
\hline PT45 & 3930 Judah St & 2014.07 & $\mathrm{NC}-1$ & Other Ave \& Seabreeze Cafe & A & $\circ$ & 0 & $\circ$ & - & WD & $\circ$ & $\circ$ & $x$ & $\circ$ & $\circ$ \\
\hline PT46 & 1901 Ocean Ave & 2014.08 & NCT & Fog Lifter Café+Ocean Ave Assoc & A & $\circ$ & 0 & 0 & - & WD & $\circ$ & 0 & $x$ & 0 & 0 \\
\hline PT47 & 201 Octavia St & 2014.08 & NCT & MERCURY CAFÉ & A & $\circ$ & - & $\circ$ & 談話 $(2)$ 、携带 $(1)$ & WD & $\circ$ & $\circ$ & $\mathrm{x}$ & $\circ$ & $\circ$ \\
\hline PT48 & 2001 Polk St & 2014.10 & $\mathrm{NCD}$ & CHEESE PLUS & $\mathrm{A}$ & $\circ$ & 0 & $\circ$ & 飲食 $(1,1)$ 、着座 $(1)$ & $\mathrm{CC}$ & $\circ$ & $x$ & 0 & $\circ$ & $\circ$ \\
\hline PT49 & 627 Cortland Ave & 2014.10 & $\mathrm{NC}-2$ & Vinorosso & A & - & 0 & 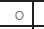 & - & WD & $\circ$ & $x$ & 0 & 0 & $x$ \\
\hline PZ01 & Jane Warner Plaza & $\begin{array}{l}2009.05+ \\
2010.5\end{array}$ & $\begin{array}{l}\text { NCD, } \\
\text { NCT }\end{array}$ & Castro CBD & $\mathrm{D}$ & $\circ$ & $\circ$ & $\circ$ & $\begin{array}{l}\text { 寝る }(1,1) \text { 、座り込む(計 } 4), \text { 着座 }(1, \\
1) \text { 、談話 }(2,2,2)\end{array}$ & $\mathrm{AP}$ & $\circ$ & $\circ$ & $x$ & $\circ$ & $x$ \\
\hline PZ02 & Guerrero Park & 2009.09 & RH-2 & Friends of Grer & $\mathrm{D}$ & - & 0 & $x$ & - & $\mathrm{AP}$ & $\circ$ & $\circ$ & $x$ & $\circ$ & $x$ \\
\hline PZ03 & Naples St. & 2010.11 & NCD & Outer Mission Merchants Assoc. & $\mathrm{D}$ & - & 0 & $\circ$ & - & SP & $\circ$ & $\mathrm{x}$ & $\mathrm{x}$ & 0 & $x$ \\
\hline PZ04 & $\begin{array}{l}\text { Persia Triangle } \\
\end{array}$ & 2014.09 & NCD & Excelsior Action Group & $\mathrm{D}$ & - & 0 & $\mathrm{x}$ & - & $\mathrm{CC}$ & $\circ$ & 0 & $x$ & 0 & $x$ \\
\hline PZ05 & Annie street Plaza & 2014.10 & $\mathrm{C}-3-0$ & YERBA BUENA CBD & $\mathrm{D}$ & - & 0 & $\circ$ & 談話(3), 飲食 $(1,1)$, 携带 (1) & $\mathrm{AP}$ & $\circ$ & $\circ$ & $\circ$ & $\circ$ & $x$ \\
\hline
\end{tabular}


表 7 用途地区指定とパークレット・プラザの関係（筆者作成）

\begin{tabular}{|c|c|}
\hline \multicolumn{2}{|c|}{ 但し、PZ01 はニつの用途に面する } \\
\hline Broadway NCD & PT02, 09, 16, 42 \\
\hline Polk St. NCD & PT07, 08, 48 \\
\hline Haight St. NCD & PT32, 40 \\
\hline $24^{\text {th }}$ St. Noe Valley NCD & PT03, 04 \\
\hline Excelsior Outer Mission St. NCD & PT24, PZ04 \\
\hline Divisadero St. NCTD & PT01, 13, 44 \\
\hline Valencia St. NCTD & PT06, 10, 11, 12, 20, 31 \\
\hline Upper Market St. NCTD & PT05, PZ01 \\
\hline 上記以外の NCD, NCTD & PT18, 19, 27, 34, 35, 38, 39, 46, 47, PZ01, 03 \\
\hline NC- $1,2,3(\mathrm{NCD}, \mathrm{NCTD}$ 以外) & PT15, 17, 21, 22, 25, 29, 43, 45, 49 \\
\hline NC 系以外の用途指定（11 箇所） & 、PZ01 は二つの用途に面する \\
\hline $\mathrm{RC}-4, \mathrm{RH}-2$ & PT24, 26, 28, PZ02 \\
\hline $\mathrm{C}-3-\mathrm{O}, \mathrm{C}-3-\mathrm{R}$ & PT14, PZ05 \\
\hline SLI, WMUO & PT30, 33, 36, 37 \\
\hline $\mathrm{M}-1$ & PT41 \\
\hline
\end{tabular}

残り 8 箇所のうち 6 箇所はバレンシア通り（Valencia Street NCD 地域内）に面する。バレンシア通りはバス路線ではないが、その 1 本東側（約 195m）にはサンフランシスコ市の骨格幹線道路の一つミ ッション通りでありバスや地下鉄 (BART) が走る。例外としては PT41 と PT30 がバス路線である 3 番通りから 1 街区裏手の位置にある。

\section{2. 空間デザインの動向}

パークレットマニュアルには人間的で好ましいアメニティとして 6つの項目（作り付けの座面、多様な利用を誘発する多様な形状、 移動可能なファニチャ、植栽、照明、駐輪設備）を挙げている。パ ークレット及びプラザのデザインについて照明を除く 5 項目注 ${ }^{12)}$ 人
の対応を見ると、全く配慮のないもの 1 件（PT23）、1 項目のみの配 慮に止まるもの 1 件（PT28）、2 項目の配慮があるもの 7 件（PT09， $12,14,18,37,39, \mathrm{PZ} 03)$ であった。残り 45 件は過半の 3 項目以上の 配慮が見られた。このように全 54 箇所のうち 45 箇所以上が過半項 目において配慮がなされていることから、大半のプラザとパークレ ットは人間的で好ましいアメニティが達成できていると言える。

パークレットは約 $20 \mathrm{~m}^{2}(34 \mathrm{feet} \times 6 \mathrm{feet}=204 \mathrm{sf})$ の広がりを有す るため、一つの空間に複数人が滞留可能である。プラザは全て交差 点や道路全体に設けられているためパークレットよりも広い。パー クレット及びプラザ全 54 箇所の内、PT23 を除く 53 箇所のパークレ ット及びプラザは、表 6 に示すとおり「着座可能な場所が備え付け (A1)」「移動式のチェアが複数設置 (A3)」のいずれかによって複数 人の着座場所が確保されている。PT23 は基盤部分が広く確保され、 テーブルとチェアを設置する空間は充分に確保されているが、2 度 の調査時にはそれらの配置が確認できなかった。

移動可能なファニチャ以外に、人が身を寄せる行為（座る・もた れかかる等）が多様かつ同時に可能なデザインかどうか（A2）とい う点では、複数人が「身を寄せる行為」ができるキャパシティがあ り、かつ人が身を寄せる行為の種類が複数確保し得る形状 (例えば、 複数の高さの座面・背もたれ等）が視認できることを基準として

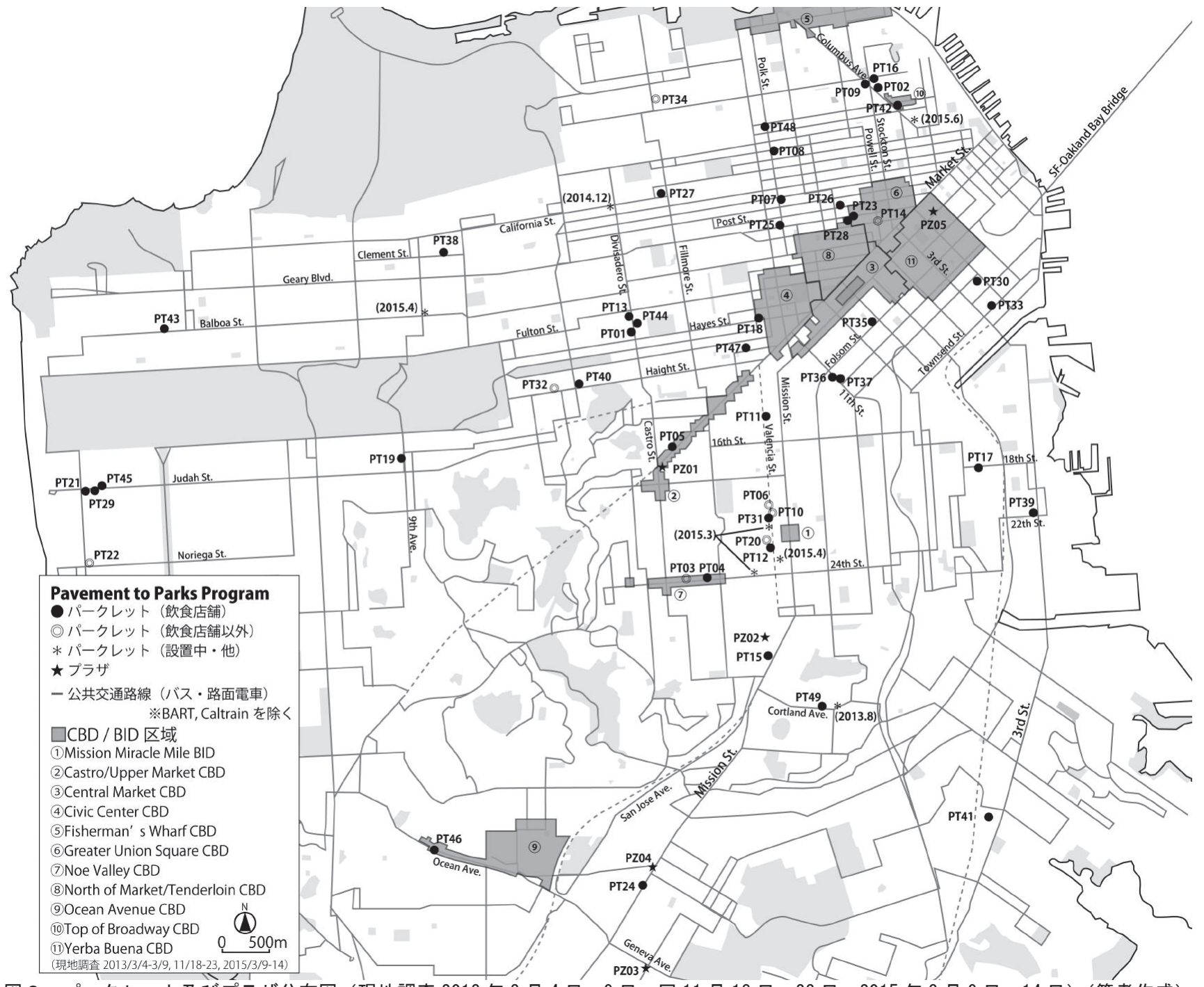

図 2 パークレット及びプラザ分布図（現地調査 2013 年 3 月 4 日〜 9 日、同 11 月 18 日〜23 日、2015 年 3 月 9 日〜 14 日）(筆者作成) 
抽出したところ、24 箇所のパークレットと 4 箇所のプラザが該当し た。このような着座場所のデザインは、不特定多数が滞留しても相 互に干渉せず滞留し続けることが可能な、包摂性の高い公共空間と してパークレットおよびプラザを成立させていると言える。

店舗とパークレットの一体感が強い場合にはパークレットが公共 空間ではなく店舗の一部に感じられてしまう恐れがある。従ってマ ニュアルにおいても店舗とパークレットのアメニティのデザインの 区別を明記している。この点を検証するため飲食店舗 42 店のうち専 用テラス席を設けている 29 店について、パークレットに設置されて いるアメニティ（テーブル、チェア、植栽プランター） と店舗前テ ラス席のアメニティの同一性を調べたところ、4 店舗 (PT01，02，13， 18）がテーブル、チェア、プランターの何れか一つ以上についてテ ラス席と同じものを使用していた。但し PT01 はテラス 1 席だけであ り、パークレットとの強い一体性は感じられなかった。PT02 はテー ブルとチェア、PT13 はテーブルについてテラス席と同一のものを使 用していた。PT18 は店舗ファサードとパークレットの植栽プランタ 一が同じ色彩・素材であるため、両者の一体性が強く感じられた。 以上のことから、PT18 を除き、公共空間としてのパークレットと商 業空間である店舗前のテラス席との区分はできていると言える。プ ラザについては、店舗が直接面するものは PZ01 だけであるが、アメ ニティに関して周辺店舗と同一のものは使用されていない。

\section{3. 空間利用の状況}

調查時に全 54 箇所のパークレットとプラザの利用状況を観察し たところ、パークレット 25 箇所とプラザ 2 箇所に利用者が確認され た。このうちパークレット 18 箇所とプラザ 2 箇所では同時に複数人 の滞留が見られた。パークレット調查時に観察された人の行動内容 と延べ数をまとめたのが表 8 である。人の行動は着座の場合が 75 人、着座せず立ち寄りの場合が 5 件と、大多数がパークレットに着 座していた。着座の 75 人のうち 41 人が飲食を伴い、34 人が飲食以 外の行動であった。飲食 41 人のうち 22 人が飲食のみだが、その他 に談話をしながら (14人 / $/ 6$ 組)、携帯操作をしながら $(2$ 人)、遊び ながら（子供 1 人）、読書しながら（1人)、PC 作業をしながら（1 人）といったように多様な行動が観察された。飲食の利用者は飲食 店舗以外においても観察され、飲食店舗前の利用者の中にも必ずし も当該店舗とは関係のない飲食をする人も観察された。これらの観 察結果から、パークレットは民間主体に設置された場所でありなが ら、自由な公共空間として実際に活用されていることがわかる。

プラザ 2 箇所については、着座して談話 $(9$ 人 $/ 4$ 組)、深く座り込 む $(4$ 人)、着座して飲食 $(2$ 人 $/ 2$ 組)、眠る $(2$ 人)、ファニチャに座 る (2 人) 、着座して携帯操作 (1) といった行動が見られた。パーク レットもプラザも共に、多様な活動を包括する自由な公共空間とし て利用されていると言える。

\section{4. 使用素材の動向}

パークレットマニュアルには「持続可能なデザインと建設」の項目 があり、維持しやすい素材の使用等が規定されている。そこでパー クレット 49 箇所及びプラザ 5 箇所に用いられている材料にはどの ような特徴があるのか分析した。データは表 6 に示す。

パークレットの基壇部（人が滞留する場所）の舗装面は、ウッド デッキ舗装 24 件、コンクリート系仕上げ舗装（ブロック舗装含む） 18 件、鉄板・グレーチング舗装 3 件、レンガ舗装 2 件、人工芝舗装
表 8 調査時に観察されたパークレットとプラザの利用(筆者作成)

\begin{tabular}{|l|l|l|}
\hline 分類 & 行動 & 詳細 \\
\hline 着座(75) & 飲食 (41) & $\begin{array}{l}\text { 飲食のみ(22), 飲食 +談話(14)(6 組),携帯(2),遊び(1), } \\
\text { 読(1), PC 作業(1) }\end{array}$ \\
\cline { 2 - 3 } & その他(34) & 談話(16)(10 組), 着座のみ(1 1),携帯(5), PC 作業(1),手芸(1) \\
\hline 着座以外(5) & 立つ(5) & 携帯(2), 談話(2)(1 組), もたれ掛かり(1) \\
\hline
\end{tabular}

2 件であった。プラザの舗装面は、アスファルト舗装 3 件（元の舗 装のまま 2 件、カラーアスファルトで再舗装 1 件)、コンクリート舗 装 1 件（元の道路舗装面のまま）、土舗装 1 件（再舗装）であった。 作り付け座面を有するパークレットおよびプラザ 44 箇所の座面の 仕上げは、木仕上げ 37 件、コンクリート仕上げ 5 件、鉄仕上げ 4 件、FRP 樹脂 1 件であった注 ${ }^{13)}$ 。一般に道路空間における舗装やファ ニチャの材料とデザインは耐久性と維持管理の容易さが重視される。 コンクリートや鉄に比べて木材は柔らかく温かみのある質感を持つ が、維持管理の面においては木材の利用は腐食や形状変化による釘 やネジの飛び出しなど、コンクリートや鉄よりも手間がかかる。し かし、パークレットの舗装面は半数以上が木材（ウッドデッキ）を 利用し、道路面には通常利用しない人工芝舗装の事例もある。作り 付けの座面については 8 割以上が木材を利用している。

テーブルやチェアなど毎日の設置・撤去が必要なファニチャ類は パークレットでは 25 箇所、プラザでは 1 箇所で設置されている。生 き物である植栽（A4）はパークレット 44 箇所、プラザ 5 箇所におい て設けられている。

\section{5. 維持管理の状況}

パークレットとプラザの維持管理の状態について、全 54 箇所を観 察したところ、ゴミ等の散乱が観察されたのは 4 笝所 (PT23，28，38, PZ04)、大幅な損傷が確認されたのは 1 箇所（PZ02、植栽プランター 損傷）のみであったことから、全体的には良好な維持管理状態にあ ると言える。維持管理状態の不良なパークレットは、いずれも飲食 店舗が提供者であった。維持管理状態の不良なパークレットとプラ ザは全て調査時に利用者は見られなかった。PT23 と PT2 28 はテンダ ーロイン地区と呼ばれる界隈のジョンズ通りを挟んで斜向かいに位 置する。この界隈はサンフランシスコダウンタウン内でも治安が悪 い地区として知られている。PZ04 は周辺に近隣店舗もなく前面道路 は自動車交通量が多い立地である。

以上のことから、ここでの持続可能なデザインとは、初期状態の 耐久性やメンテナンスフリーであることではなく、頻繁な維持管理 と修繕を前提としたものであることがわかる。

\section{4. プラザおよびパークレットの整備と日常的な維持管理}

$\mathrm{P} 2 \mathrm{P}$ プログラムに加わった地元組織のうちヒアリング調查への 協力が得られた 5 団体の手がけた 3 箇所のパークレットと 3 箇所の プラザについて、整備の背景と目的、デザインと整備プロセス、維 持管理の方法と課題を調查した。その内容を表 9 に整理し、ここか ら共通点を抽出したものが表 10 である。

整備目的については、プラザはイベントや活力や賑わいをもたら す広場空間（空地）であることが目的とされている。パークレット は歩行者や飲食店舗利用者の休数区間の確保が目的とされている。 Powe11 通りと0cean 通りの 2 箇所のみであるが美観形成も目的とさ れている。

デザインと整備のプロセスについては、プラザは活用ポテンシャ 
ルの見極め、期間限定、整備費用負担軽減などを理由にまず暫定整 備として実施され、その後に本格的整備が実施もしくは構想されて いる。CBD 法人が整備した 2 箇所は上位計画の位置づけを有する。 暫定整備の段階では、舗装の着色やファニチャ配置などの簡易で素 早い安価な整備が導入されている。パークレットに関してはプロセ スの共通点は抽出されなかった。DIYによる素早い安価な整備もあ るが、89 万ドルもの予算をかけた整備もあった。

維持管理に関しては、プラザとパークレット共に日常的には清掃 が、植栽を有する場合はその維持管理が共通して行われている。プ ラザでは充分な人件費が確保されている 1 箇所は防犯パトロールを 日常的に実施するが、その予算がない他 2 箇所では防犯が課題とな っている。日常的にイベントを実施する CBD の 2 箇所では、イベン トの充実が課題となっている。パークレットではハード面において 修繥費負担が、ソフト面において美化や清潔さの保持が課題に上げ られ、いずれも資金負担の問題として理解できる。

表 10 パークレット及びプラザ整備·維持管理の共通点（筆者作成）

\begin{tabular}{|c|c|c|}
\hline & プラザ & パークレット \\
\hline 目的 & $\begin{array}{l}\text { @広場空間の確保 (イベントできる広場、 } \\
\text { 活力る } \\
\text { す公共的な空地) }\end{array}$ & 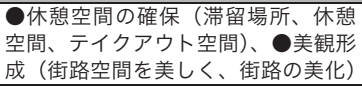 \\
\hline $\begin{array}{l}\text { デザイ } \\
\text { ン•整備 } \\
\text { のプロ } \\
\text { セス }\end{array}$ & $\begin{array}{l}\text { 暫定整備から本格的整備へ（活用 } \\
\text { ポテンシ見極めるための暫定 } \\
\text { 整備、期間限定の暫定整備、整備費 } \\
\text { 用を理由とする暫定整備） }\end{array}$ & ※共通点は抽出されず \\
\hline $\begin{array}{l}\text { 維 持 管 } \\
\text { 理 }\end{array}$ & $\begin{array}{l}\text { 9日常：清掃と植栽の維持管理を実施、 } \\
\text { ○維持管理の課題：防犯（安全の維持、 } \\
\text { 防犯スタッフ確保)、イベント充（夏 } \\
\text { 期イベント充実、好ましい利用の創出） }\end{array}$ & $\begin{array}{l}\text { 9日常：清掃と植栽の維持管理を実施、 } \\
\text { ○維持管理の課題：資金負担（高額 } \\
\text { な修理修繬費の負担、美化や清潔さ } \\
\text { の保持） }\end{array}$ \\
\hline
\end{tabular}

\section{5. 考察}

\section{1. まとめ}

パークレット及びプラザの立地動向としては、設置・整備されて いる道路の半数以上が近隣商業型の路面店の集積によって特徵づけ られていること、大半は公共的なアクセスが得られやすい（不特定 多数が利用しやすい）立地にあることが明らかになった。デザイン の特徴については以下の四点が明らかになった。第一に、人間的で 好ましいアメニティが達成できていること。第二に、着座空間のデ ザインは、不特定多数が滞留しても相互に干渉せず滞留し続けるこ とが可能な、包摂性の高い公共空間としてデザインされていること。 第三に、公共空間としてのパークレットと商業空間である店舗前の テラス席との区分はほぼできていて、パークレットもプラザも共に、 多様な活動を包括する自由な公共空間として利用されるデザインと なっていること。第四に、公共空間として人にとっての居心地の良 さが重視されており、ここでの持続可能なデザインとは、初期状態 の耐久性やメンテナンスフリーであることではなく、頻繁な維持管 理と修繕を前提としたものであること。

地元組織が設置に係わったプラザとパークレットの事例調查から、 計画・デザイン・整備・維持管理に関して以下の共通点が明らかに なった。第一に、プラザは道路における広場空間の確保が目的に設 定されていること、パークレットは休㮩空間の確保に加えて美観形 成が目的とされていること。第二に、プラザのみ暫定整備がまず行 われ、その先に本格的整備が実施または構想されていること。第三 に、プラザは防犯など好ましくない利用の抑制とイベントなど好ま しい利用の促進が維持管理の課題となっていること。パークレット
ではハード面での修繥費の負担やソフト面での清掃などケースごと に維持管理の課題は異なるが、一口で言うと資金負担の問題に集約 できる。

\section{2. 考察 1：いかに人間中心の道路空間を創出するか?}

パークレットとプラザによるサンフランシスコの道路の広場化デ ザインは以下の点において道路に人間中心の場所を創出するものと 考えられる。

第一に、道路における「利用者視点での公共性」の創出。パーク レットは不特定多数が相互干渉せず滞留し続けられるよう着座空間 がデザインされており、人間的で包摂性のある空間を道路上に生み 出している。大半のパークレットは店舗によって維持管理されてい るが商業的利用はされず、デザイン・管理の面において店舗と区別 されている。パークレットとプラザの設置・整備主体は管理者とい うより公共空間の提供者 (host) として認知されている。マニュア ルでは設置場所と基本構成要素が標準化されているが、利用者にと ってのインターフェースとなる部分のデザインは作り手の自由度が 高く、多様なデザインを生み出している。何れも利用者視点での公 共性を創出していると言えよう。パークレットは市域全体に広がり 多数設置されている点において既に市民権を得ていると考えられ、 このことも利用者視点での公共性を下支えしている。

第二に、道路における「人の居心地の良さ」の創出。パークレッ トとプラザでは、頻繁な維持管理と修繥を前提とした、耐久性より も人間的で好ましいアメニティが優先され、これが居心地の良さを 提供していると考えられる。イベント活用、安全性、美観が重視さ れている点も人の居心地の良さを高めていると考えられる。

プラザ整備に見られる暫定整備のプロセスは、実験的な導入を通 じて様々な課題の検証とともに地域コミュニティの共感を促進する こと、時限的な試行錯誤の機会であることを活かして耐久性よりも 雰囲気や創造性を優先させるデザインを可能にしていること、の二 つの点において「利用者視点での公共性」と「人の居心地の良さ」 の両者を引き出すプロセスを提供していると考えられる。

\section{3. 考察 2：日本の道路の広場化を進める際の課題}

日本における道路空間の活用は、国交省による道路占用許可に関 する弾力的な運用基準と諸制度による規制緩和、道路の社会実験、 エリアマネジメント組織等を主体とする道路空間の一体的な利活用 と維持管理等の展開を経て、道路空間の多機能化・オープン化の方 向へと進んでいる注 17)。それを踏まえ、日本における道路の広場化 の推進には次の二つの課題が指摘できよう。

一つは、道路の広場化を推進する社会実験のあり方である。近隣 組織によるプラザ整備では、まず暫定整備が実施され次に本格的整 備が実施または構想される流れで進んだ。これは日本であれば社会 実験から本格的整備に至るプロセスと同様のものとして理解できる。 こうした広場化プロセスを想定する場合、道路の社会実験注 18) が道 路施策の導入に先立つ当該施策の試行・評価を目的とすることを踏 まえ、人間中心の道路空間としての「居心地の良さの向上」と「利 用者視点での公共性を創出するデザイン」のあり方を道路施策の中 に明示し、それらを適正に試行・評価する社会実験をいかに構築す るかが課題となる。

もう一つは、道路の広場化と維持管理を分担できる多様な主体に ついての制度的位置づけである。パークレット提供者の大半は飲食 
表 9 ヒアリング調査の対象となったプラザとパークレットにおける整備・維持管理動向まとめ（筆者作成）

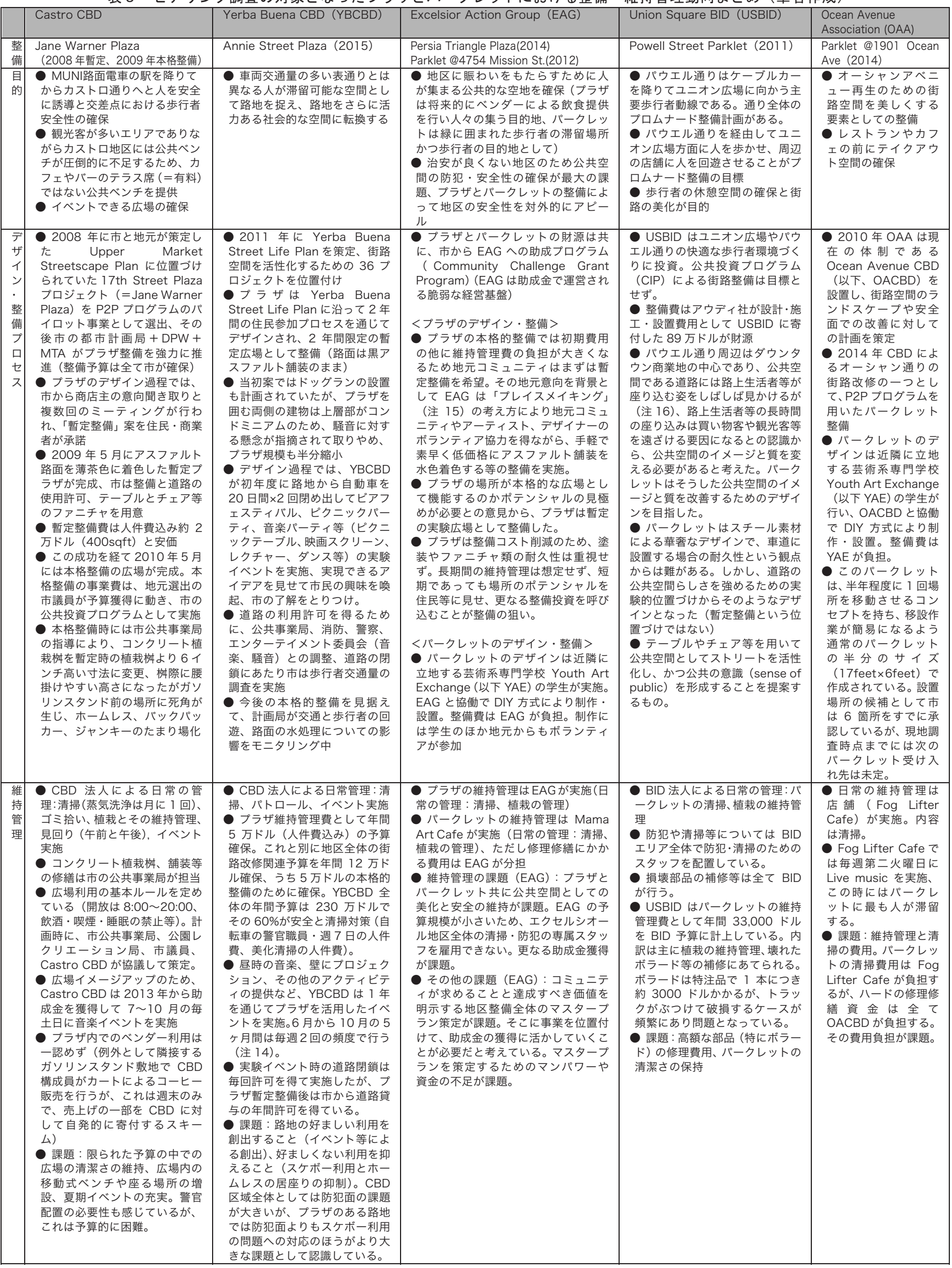




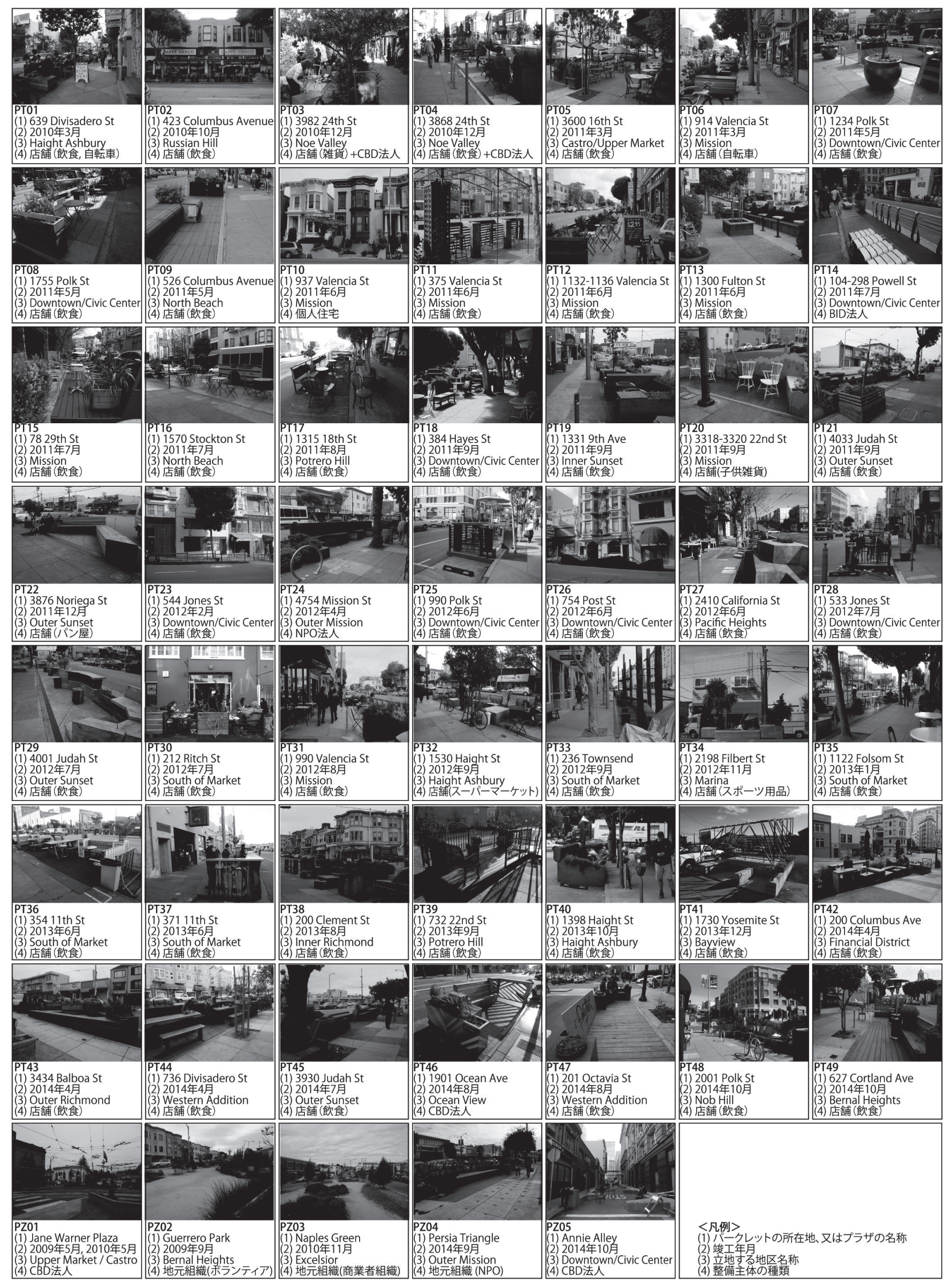

図 3 現地調査を行ったパークレット及びプラザの写真一覧（筆者作成） 
店舗であり、エリアマネジメントを担う近隣組織だけに留まらない。 これは提供者がパークレットを維持管理する必要はあっても、道路 空間としての一体的な利活用を実施・促進する必要がないためだと 考えられる。この状況は、地域の多様な主体が公共空間であるパー クレットの整備・維持管理を分担している状況であり、近隣組織だ けに広場化の負担が集中しないメリットを生み出していると考えら れる。日本では、最近になって道路協力団体の登録制度の検討など、 道路の維持管理を地域全体で共有していく方向性が国交省により示 されている注 19)。こうした方向性と道路の広場化の取り組みを明確 に結びつけ、清掃や除草を目的とする団体だけでなく、居心地の良 い公共空間の提供に関心を持ち実践し得る主体も道路の維持管理を 分担できることを制度的展開の中で位置づけることが課題と言える。

\section{参考文献}

1) Gary Benjamin: Partnering with Business Improvement Districts to Create "Streets for People" Parklet Plazas in Los Angeles: A Study of BID Partnerships in New York City and San Francisco Parklet Projects, A comprehensive project submitted in partial satisfaction for the requirements for the degree Master of Urban \& Regional Planning, 2013.9

2) Larson,C.,Guenther,J.:Parklets planning with place-making in mind rationale and strategy for municipal planners, Plan Canada, Vol.52, No.2, pp.43-47, 2012.6

3) Evan F. Peterson: Using Pilot Projects to reclaim Public Space For Pedestrians: Lessons from New York City and San Francisco, A THESIS SUBMITTED IN PARTIAL FULFILLMENT OF THE REQUIREMENTS FOR THE DEGREE OF MASTER OF ARTS (PLANNING), The University of British Columbia, 2012.8

4) San Francisco Planning Department: Citywide Assessment of Parklets \& Plazas, Summary of Data Collected for Summer 2014 Public Life Study, prepared by Justin Panganiban, Robin Abad Ocubillo, 2014

5) San Francisco Great Streets Project: 17 th Street Trial Plaza User and Perception Analysis: Summary of data collected between May 6th and June 13th, 2009

6) San Francisco Great Streets Project: Divisadero Trial Parklet Impact Report: A summary of data collected before and after the installation of the Divisadero trial parklet, 2010.5

7) San Francisco Great Streets Project: Parklet Impact Study, 2012.1

8)渡邊・村山・清水：サンフランシスコの”Parklet”の制度とデザインに関す る研究，日本建築学会大会学術講演梗概集，都市計画,pp.497-498, 2014

9) 中島直人: ニューヨーク市における道路空間の広場化, 都市計画, Vol. 63, No.6, pp. 24-27, 2014.12

10）三浦・出口：ニューヨーク市における「プラザプログラム」の運用方法 と課題, 日本建築学会大会学術講演梗概集, 都市計画,pp.499-500, 2014

11）泉山・小林：地方都市型エリアマネジメントの視点から見た「都市再生 整備推進法人」制度に関寸る研究, 日本建築学会大会学術講演梗概集, 都 市計画,pp.827-830, 2013

12）三浦・出口：旭川市平和通買物公園の利活用とマネジメントに関する研 究, 日本建築学会計画系論文集, Vol.80, No.713, pp.1635-1643, 2015.7

13) Parklets, Plazas and Temporary Programs \& Projects Outside of San Francisco, http://pavementtoparks.sfplanning.org/map-globe.html（参 照 2016.3.10)

14) Bryan Goebel: Andres Power Helps Lead a Streets Renaissance One Parklet at a Time, http://sf.streetsblog.org/2011/05/09/andres-powerhelps-lead-a-streets-renaissance-one-parklet-at-a-time/, 2011.5.9

15) Pavement to Parks Program, http://pavementtoparks.sfplanning.org/ (参 照 2016.3.10)

16) Pedestrian Plaza Proposal Package, http://pavementtoparks.sfplanning. org/docs/P2P_Plaza_Proposal_Package_v1.0.pdf (参照 2016.3.10)

17) San Francisco Planning Dept.: Transforming the Public Realm in San Francisco: activating Public Space and Prioritizing Pedestrians, NACTO Designing Cities Confrerene, 2014.10.24

18) San Francisco Parklet Manual, http://pavementtoparks.sfplanning. org/docs/SF_P2P_Parklet_Manual_2.2_FULL.pdf（参照 2016.3.10）

19) San Francisco Zoning Map, http://www.sf-planning.org/?page $=1569$ (参照 2016.3.10)
20) San Francisco Planning Code, http://www.amlegal.com/nxt/gateway .dll/California/planning/planningcode? $\mathrm{f}=$ templates $\$ \mathrm{fn}=$ default.htm $\$$ 3.0\$vid=amlegal:sanfrancisco_ca $\$$ sync=1（参照 2016.3.10）

21) Portable Parklet, http://pavementtoparks.sfplanning.org/Portable Parklet（参照 2016.3.10)

22) Excelsior Parklet Project, http://www.eagsf.org/excelsior-parklet-project.html (参照 2016.3.10)

23）国土交通省：道路空間の多機能化・オープン化, http://www.mlit.go.jp/ common/001094409.pdf（参照 2016.3.10）

24）国土交通省：社会実験の推進, http://www.mlit.go.jp/road/demopro/ (参 照 2016.3.10)

25）山崎一邦：道路協力団体制度を創設、収益活動で原資捻出, http://www.nikkeibp.co.jp/atcl/tk/15/433782/021200226/, 2016.2.19

注

注1）当該テーマへの関心は近年高い。2014 年には公益(社)日本都市計画学 会が「人間中心のみち空間へ〜デザインとマネジメントの新展開〜」と する記事を特集し、「人間中心のみち」へ向けた空間の作り方・使い方 の変革をテーマに、まちづくり・都市デザイン・交通計画の観点を複合 的に踏まえ、近年の事例からその到達点の理解と課題展望を試みている。

注2）サンフランシスコ市の H P には全米・世界のプラザおよびパークレッ 卜の計画・導入事例が地図上に紹介されている。参考文献 13 を参照。

注3）現在 P2P プログラムは「パークレット」「プラザ」「プロトタイピン グ」の 3 施策によって構成される。プロトタイピングとは道路上に人が 滞留するための新しい場所を創出する様々な試作品をつくるプロジェ クトである。移動式の駐輪柵、移動式パークレット、路上舞台、移動式 の路上公園、壁面アート、プロムナード、試作品の見本市等が市 HP で 紹介されているが、現地確認できなかったため調査対象から除外した。

注4）参考文献 1 を参照。注 5) 参考文献 14 を参照。

注6）参考文献 15 を参照。注 7) 参考文献 16 を参照

注8）サンフランシスコでは商業エリアの大半が混合用途であることから, BID 制度の他に Community Benefit District（CBD）制度を 2004 年 3 月に条例化している。CBD は不動産所有者、ビジネスライセンス所有 者、その両方を所有する者に対して地元ビジネスと不動産の利益に対す るサービスと改善のための事業資金の特別徴税を行う仕組みである。

注9）近隣商業系の用途区域（NC 地区）は近隣商業地区（NCD）と近隣商業交 通地区（NCTD）に大別される。共に近隣商業店舗の集積地区だが、NCTD は低層階が近隣商業かつ上層階が住宅の混合用途で、近隣の公共交通網の 集積に対応して中〜高密度開発を誘導する地区に区分される。NCDには近 隣商業の拠点集積 $(\mathrm{NC}-1)$ 、小規模な路線型集積 $(\mathrm{NC}-2)$ 、中規模な路線 型集積（NC-3）、小規模ショッピングセンターやスーパーマーケットを含 む集積（NC-S）と地域特性を踏まえた近隣商業地区（Named NCD）があ る。NCTD にも同様の 4 区分（NCT-1,2,3, Named NCTD）がある。

注10）現地調查により全て確認した。住居表示上はバス通りと直行する側の 路線に位置するが、交差点の直近にあるパークレットもここに含めた。

注11）例えばパークレットが 4 つ多数設置されている Polk 通りでは 19 番のバ スが運行する。起終点の Beach 通りから Market 通りまで距離約 $3300 \mathrm{~m}$ の 直線区間には 23 の停留所があり、停留所間の平均距離は $150 \mathrm{~m}$ となる。こ れは徒歩 2 分程度の距離である。バス停留所の具体的位置はサンフランシ スコ市交通局ウェブサイト https://www.sfmta.com/を参照。

注12）安全性を考慮して全ての調査は日中に実施した。従って照明が点灯する様 子が確認できないことから照明を分析対象から除いた。

注13）仕上げ材 2 種類を用いたパークレットが 3 件のため延べ件数 47 件となる。

注14）例えば現地調査を行った 2015 年 3 月の 1 週目はミュージシャン招聘、 ヨガ教室を実施。翌週はフードトラックでピザ店舗を実施。イベントの 様子は Annie Street Plaza の Facebook ページにて閲覧できる。

注15）サンフランシスコでは路上での座り込みや睡眠を 7 時から 23 時の間 は禁止とする条例を 2010 年に可決している。

注16）プレイスメイキングとは、公共空間が健康で幸せな人間的生活の場となる ことを目指し、そこでの活動や場所のイメージとデザインの質を、地域コ ミュニティと共に転換するプロセスの総称である。公共空間という言葉は 抽象的で無性格な印象を持つが、それを人間が幸せを感じるような、美し く人間味のある意義深い「プレイス」へと転じる街づくりが目標である。

注17）参考文献 23 を参照。注 18）参考文献 24 を参照。

注19） 2016 年 2 月の時点で、道路協力団体の登録制度が国交省により検討 されている。これは、道路の清掃や除草等を行うボランティア団体等と 連携して、道路の安全確保や利便性向上を図ることを狙いとする。維持 管理への協力への見返りとして道路占用許可手続きの簡略化、無余地性 の基準の適用除外による収益活動への展開（収益を道路の維持管理に充 てる場合）も想定されている。詳細は参考文献 25 を参照。 


\title{
A STUDY ON THE PARKS DESIGN OF STREETS IN SAN FRANCISCO
}

- Making a human centered street by the Parklet and Plaza -

\author{
Arata ENDO* \\ * Assoc. Prof., Dept. of Urban Design and Planning, School of Architecture, Kogakuin University, Dr.Eng.
}

This research aims to analyze the "parklet" and "plaza" generated by the Pavement to Parks Program in U.S. San Francisco and to consider the main point in the case of planning, designing and using a street as a place for people's exchange and stationary.

It become clear that the half of streets which parklet and plaza are installed have characterized by concentration of neighborhood shops and have the location which public access is easy to obtained. The design of parklet and plaza has attained pedestrian friendly and desirable amenity for people. And also it is the design as inclusive public space which people can continue to stay without interference mutually. The parklet as public space and the sidewalk seat in front of the cafe is articulated and both parklet and plaza serve as open space which includes people's various activities. In addition, sustainable design here assumes not to maintenance-free and durability of initial condition but to frequent maintenance and repair. It also become clear that the purpose of plaza project is the making people's place on the street and the purpose of parklet project are street beautification and to put the rest space. As for the plaza, the temporary one is built first and then improved in full-scale. And it is the issue that not only a control of the undesirable use such as crime prevention but also a promotion of the desirable use such as an event. As for the parklet, the maintenance issues for each cases, such as a cleaning, a burden of the repairing cost in a hardware, and so forth. It can be summarized in the problem of fund.

It is considered that the pavement to parks program create a place of human-centered on the road. Seating space of parklet is designed so that many and unspecified persons may not carry out mutual interference but may continue to stay, and also to be a inclusive humane space on the street. The installer of parklet and plaza has been recognized as a host rather than maintenance administrator. Although maintenance of a parklet is managed by the shops in front, it is not use for commercial. Design and use of parklet and shops are separated. Although the parklet manual shows the guideline of its location criteria and design elements, the its design is diverse, in particular, the part of user interface. It would say that parklet create a public open space on the street in the user's point of view.

In parklet and plaza design, priority seems to be given to humane and desirable amenity over the durability that assumes the repair and frequent maintenance. It is thought that this design offers comfortableness. Event use, safety, and aesthetic are contributed to comfort for people, too.

The process of temporary plaza improvement promotes sympathy and agreement formation of a local community with verification of their various subjects through its experimental introduction. By trial and error, it enables the design which gives priority to atmosphere or creativity over durability. It is thought that these two points offer the process of both the publicness in a user viewpoint and the people's comfortableness. 